\title{
POSITIVE AND NEGATIVE EXTERNALITIES OF MANAGEMENT ILLUSTRATED BY THE CASE OF AGRICULTURAL PRODUCTION
}

\author{
Barbara Gołębiewska $^{1 \bowtie}$, Tomasz Pajewski ${ }^{1}$ \\ ${ }^{1}$ Warsaw University of Life Sciences, Poland
}

\begin{abstract}
This study investigates the problems of convergence between objectives of agricultural producers and consumers. It states that nowadays, increasingly often, the farmers' products have no market price (are not marketed) but are either demanded by the society (positive externalities) or the society is interested in discontinuing their production (negative externalities). This study also outlines the key problems that arise from costs and benefits associated with agricultural externalities. The social costs that may be generated by modern agriculture, and the solutions used to restrict the same, were covered by this analysis. The literature on the subject and the Polish FADN databases were used. It was found that farms of environmentally friendly producers failed to collect enough payments to compensate for running a green business.
\end{abstract}

Keywords: natural environment, agriculture, private and social costs and benefits, externalities

\section{INTRODUCTION}

Agricultural production has many social functions. From the farmer's perspective, it is an activity run primarily on a for-profit basis, allowing farmers to provide for their families and to upkeep the functioning of their workplace. The agricultural sector plays a strategic role in the country's economic growth. Despite its small contribution to GDP, it plays a key role from the social perspective, producing food and raw materials for food production.
Traditionally, agriculture used to have many functions. Farmers produced food, tools and clothes, and processed their products (Wilkin, 2011). As a consequence of the development and further specialization of agricultural production, the functions of farms have become restricted to food production. Today, it becomes clear that agriculture is getting to play an increasing number of roles, although these differ in nature from one another. According to Kutkowska (2012), the roles extend to economic, social, environmental and cultural aspects which are of local, regional, national or even global significance. Thus, the consensus is that agriculture produces not only market goods (of economic significance) but also serves as a "manufacturer" of products which though not directly marketed - are demanded and "consumed" by the society. As emphasized by Wilkin, these products are of increasing significance for the society (Wilkin, 2010). This was also pointed out by Czyżewski and Czyżewski (2013) who indicate that in addition to market goods, public goods are also of importance for the development of agriculture.

In agriculture, depending on the land use type (intensive or extensive production), non-market products may generate benefits or costs (lost benefits) both for the society and for the owner of productive inputs, the farmer (manufacturer). As pointed out by Grosse, the society has become increasingly aware of this issue. Already in the 1980s, the growing environmental problems faced by rural areas were accompanied by a shift in the

\footnotetext{
PhD hab. Barbara Gołębiewska, prof. WULS, Production and Services Economics Department, Warsaw University of Life Sciences, 166 Nowoursynowska St., 02-787 Warsaw, Poland, e-mail: barbara_golebiewska@sggw.pl, https://orcid.org/ 0000-0003-4073-5274
} 
attitude of British consumers who started to call for an improvement in the quality of products and a restriction of the environmental degradation caused by agriculture (Grosse and Hardt, 2010).

Cooper et al. (2009) point out that the purpose of farming is to generate products (raw materials for production) that yield an income. However, this would be impossible without incurring specific social costs. Higher levels of production intensity involve negative effects imposing a greater burden on the environment. As indicated by Buks et al. (2016), higher intensity has an impact on food safety caused by multiple factors, including the use of measures that boost yields while threatening the natural environment.

This study attempts to present and assess social costs and benefits that arise from agricultural production, including the effects not related to the market. This issue has been addressed by researchers increasingly often. However, its nature makes it difficult to measure, as confirmed by Baumol and Oates who stated that externalities are a simple concept, which at the same time is very "difficult to grasp" (Baumol and Oates, 1988).

This study is both descriptive and analytical. It presents the issue of compatibility of objectives followed by agricultural producers and consumers. Also, it lists the major problems arising from costs and benefits associated with agricultural externalities. This study relies on the analysis of secondary data (existing sources). Based on relevant literature and the Polish FADN database, it specifies the social costs that may be generated by modern agriculture and the solutions used to restrict the same.

\section{EXTERNALITIES OF AGRICULTURAL PRODUCTION}

There is no single view on the definition of external costs and effects. Some researchers tend to define externalities in a different way, by putting them in a broader context. This definition extends to multiple aspects which are often immeasurable, whereas external cost refer to measurable components (Graczyk, 2005). It is assumed that external costs emerge if side effects of production or consumption are not taken into account in market prices (Samuelson and Nordhaus, 2006). Externalities have an impact on costs incurred by (or welfare of) customers. Stiglitz describes this as a process which consists in transferring a part of costs or benefits resulting from the activity of an operator to other parties without a corresponding payment (Stiglitz, 2004). A similar stance was taken by Zegar (2012) who specified two criteria for the classification of externalities. The first one is the type of impact on other parties which may either reduce the benefits enjoyed by others (when negative effects arise) or improve the well-being of others (when positive effects arise). The second criterion is ownership, and is used to classify externalities into private and public effects.

Some researchers perceive externalities as equivalent to costs, claiming that negative externalities are external costs, while positive externalities are external benefits. Already in the 1980s, Moffat indicated that these were external costs or effects (Moffat, 1984). Similarly, Kamerschen et al. (1991) stated that positive externalities are referred to as external benefits while harmful externalities mean external costs. It can also be concluded that negative externalities generate costs which are borne by one of the parties who contribute to generating and participate in "taking advantage" of the externality.

According to Pretty et al. (2000), externalities generated in the agricultural sector have five features:

- their costs are often neglected,

- they often occur with a time lag,

- they often damage groups whose interests are not well represented,

- the identity of the source of the externality is not always known;

- they may lead to erroneous economic and political decisions (solutions).

The above features show the significance of externalities which - though difficult to measure - have a perceptible impact on society.

Agricultural production depends indirectly on environmental conditions. The changes to the environment resulting from agricultural production processes are primarily driven by the intensity of agricultural production which keeps growing and has reached a level at which it usually leads to environmental degradation. In regions where traditional (extensive) farming prevails, agricultural activity contributes to preserving the specific features of the environment and landscape. Thus, the continued growth of agricultural production is important as

1 "Taking advantage" of negative effects refers to a situation where an individual is unable to impact or prevent the emergence thereof (as it is the case, for instance, with the emergence of smog). 
it should follow a pattern which does not threaten the environment and even generates additional positive effects.

\section{PRIVATE AND SOCIAL COSTS AND BENEFITS OF FARMING}

The development of modern agricultural production methods has resulted in increasing the number of negative effects. Some of them were either neglected or have not been experienced in the past. Extensive production did not pose the same environmental threats as intensive production. The threats are undoubtedly associated with the emergence of externalities and related costs which, until recently, have not been taken into account when calculating the economic profits and losses of manufacturers (private costs) or consumers (social costs).

Another example is the excessive use of mineral fertilizers or plant protection agents. The manufacturers, interested in getting higher yields, are inclined to use greater doses of fertilizers or protection agents which, if used excessively, cannot be absorbed by the environment. The resulting pollution affects the products, soil and water. This leads to negative effects for the society, including the deterioration of food quality (and thus increased health problems) (Borowy and Kubiak, 2014; Piskuła et al., 2011), landscape degradation, threats to biodiversity etc. From the manufacturer's perspective, the optimum level of production intensity is the "farm optimum" point (Fig. 1).

An increase in expenditures does, in fact, lead to a decrease in marginal profit; nevertheless, the overall profits grow to reach the "farm optimum" point. Thus, every producer is interested in increasing the profits (from the economic point of view). At a certain point of increase in production intensity, social costs emerge which may be associated with environmental pollution, for instance. Therefore, considering the social benefits, no additional expenditure should be borne beyond the "social optimum" point. However, from the private

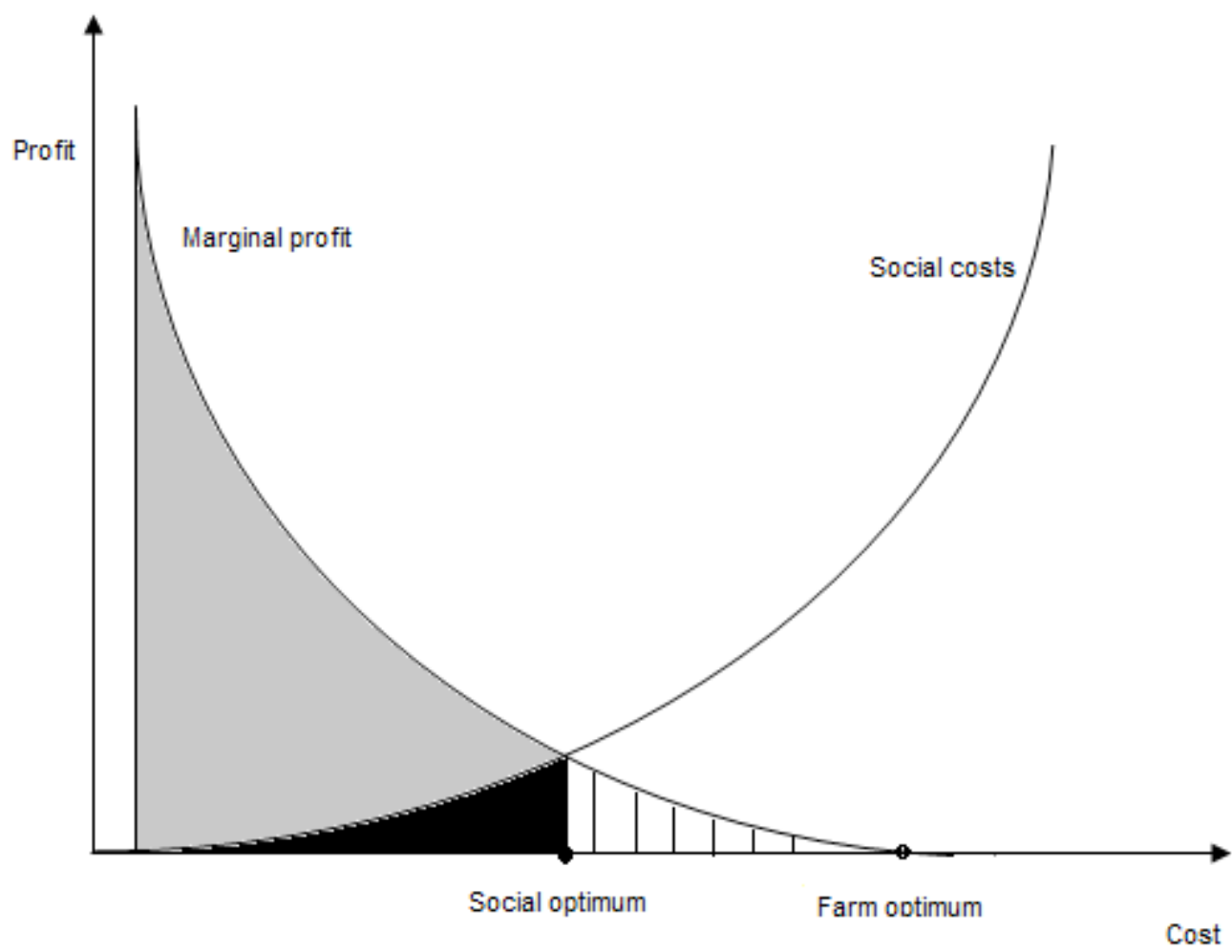

Fig. 1. Private and social costs and producer profits at different production intensities Source: Reisch and Zeddies, 1995 (after: De Haen, 1989). 
point of view, the profit would be "incomplete" at this point. It would be possible to earn additional profits at the expense of social losses which may be associated, for instance, with a deterioration in food quality, a threat to animals etc.

This problem was viewed in a similar way by Begg et al. (1999) who indicate that production externalities with negative consequences result in a widening gap between private and social marginal costs of production. This aspect was analyzed by Gołębiewska (2011) who pointed to the problem of how to compensate the manufacturers for generating positive externalities. In the case of externalities of consumption (with positive consequences), social benefits emerge. This emphasizes the difference between private and social marginal benefits (Fig. 2).

The private marginal cost and social marginal cost become equal $(K p, K s)$. The private marginal benefit is represented by curve $\mathrm{D}$.

The market equilibrium is at point A. However, the beneficial externalities of consumption lead to a situation where the social marginal benefit exceeds the private marginal benefit. The socially effective production is denoted by point $\mathrm{B}$. It represents a production volume $Q_{1}$ which (unlike $Q_{2}$ ) is not effective from a private point of view. It can thus be stated that free market leads to emergence of a social loss which is equal to the area of triangle $\mathrm{ABC}$.

Examples of social costs in agriculture include those associated with the need to reduce water pollution (caused by fertilizers) or the exclusion of a part of land from agricultural use (in return for an adequate compensation) due to the presence of assets which are particularly valuable for the environment and may restrict the production of goods by the farm.

The emergence of such contradictions makes it necessary to provide farmers with compensation for lost benefits, so that the producer does not incur losses while the society benefits and vice versa. However, due to incomplete information, it is difficult to determine who, for what and how much should be rewarded. Therefore, attempting to estimate such costs and benefits is a great challenge.

According to Pretty et al. (2000), environmental economists devised methods to assess societal

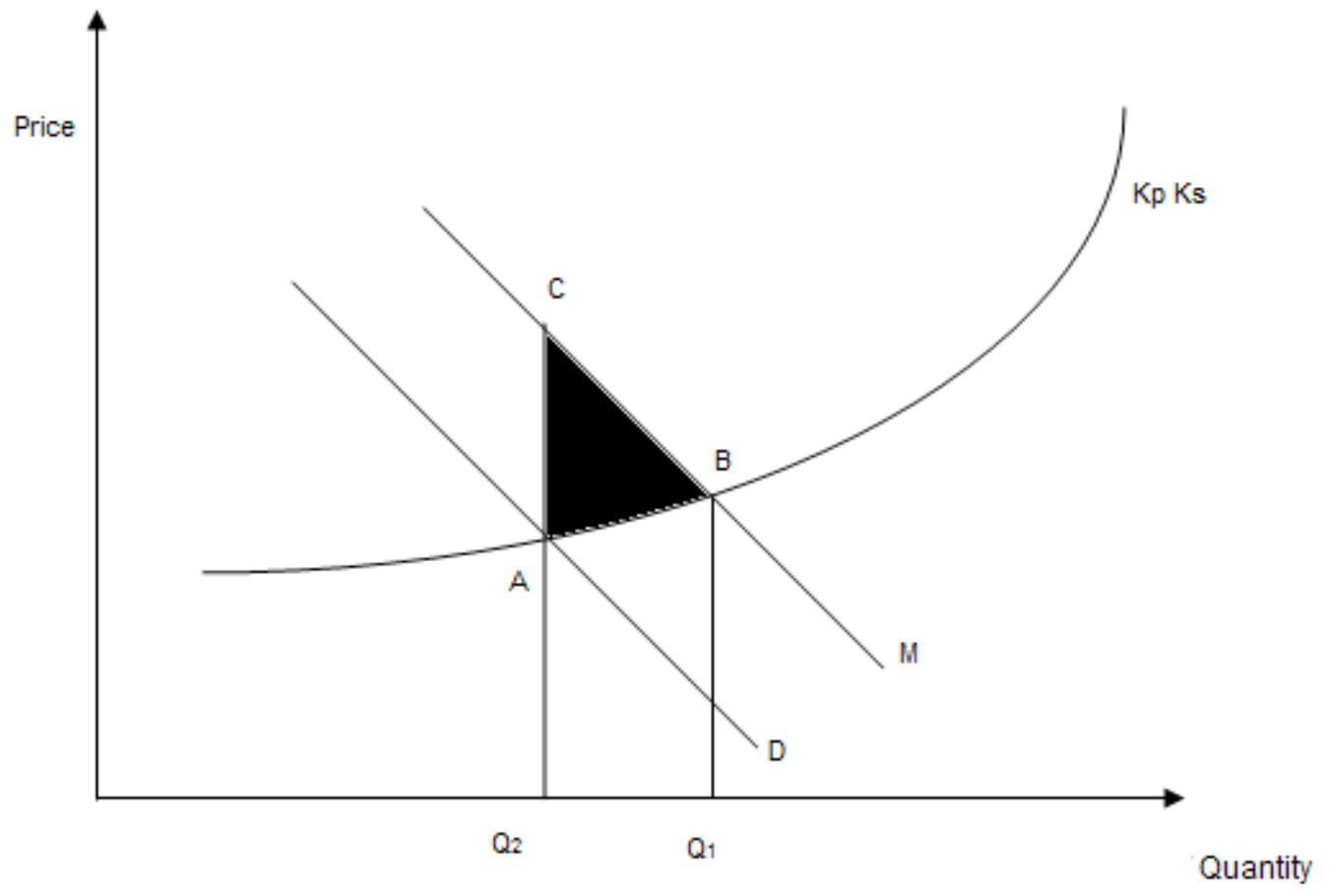

Fig. 2. Beneficial externalities related to consumption Source: Begg et al., 1999. 
preferences with regard to environmentally friendly products with the use of hypothetical markets. The value of environmental goods and services is expressed by the society's "willingness" to pay for these products.

The issue of market inefficiency in terms of externalities was presented by Boardman et al. (2006), Rosen and Gayer (2008) (quoted after: Jongeneel et al., 2014). The basic sources of this inefficiency were presented in graphic format, using the example of a negative externality (Fig. 3). The line sloped upwards reflects the agricultural supply curve, which is the same as the marginal cost curve. This correlation reflects private costs associated with a certain level of production. Curve D illustrates the marginal benefits for the consumer.

Apart from private costs, the society also bears social costs associated with agricultural production. These are the negative effects of prosperity due to negative externalities (e.g. environmental damages). As a result, in the agriculture, the social cost curve lies above the private cost curve. Without any intervention, the free market equilibrium is located at $Q_{\text {act }}$, the intersection of demand and supply curves. However, at this point, the social costs for a marginal production unit go beyond the private producer's willingness to pay. From the social point of view, optimum allocation is reached at the intersection of the social cost curve and demand curve $\left(Q_{\text {opt }}\right)$. In general, it can be stated that when externalities come into play, market equilibrium is sub-optimal, as it leads to excessive supply of negative externalities. The triangular area in the diagram represents an estimation of social losses associated with such negative effects.

Then how can this ineffectiveness be prevented by bringing points $Q_{1}$ and $Q_{2}$ closer to each other? At present, such activities take the form of compensations for farmers who comply with sustainability rules (e.g. the farming/environmental/climate payments) (Brodzińska, 2013; Gołębiewska and Pajewski, 2016; Mroczek et al., 2013; Sadowski and Czubak, 2010). As a part of the Common Agricultural Policy, the agri-environmental programs (since 2014, the agri-environment and climate payments) are designed to support the green management methods. In order to access the payments, the farmers voluntarily commit themselves to environmental protection.

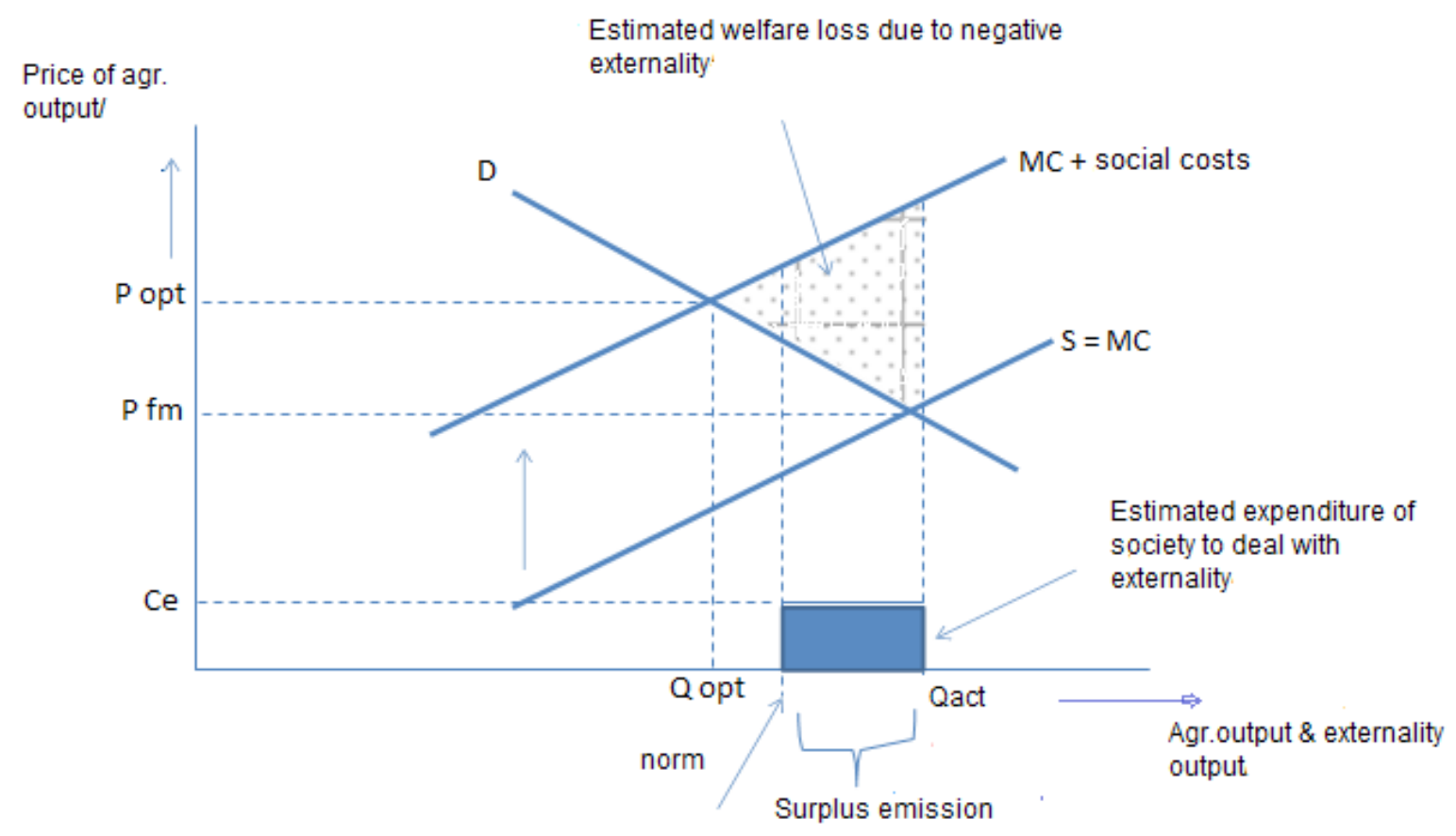

Fig. 3. Negative externality, optimal allocation and cost calculation Source: Jongeneel et al., 2014 (after: Boardman et al., 2006; Rosen and Gayer, 2008). 


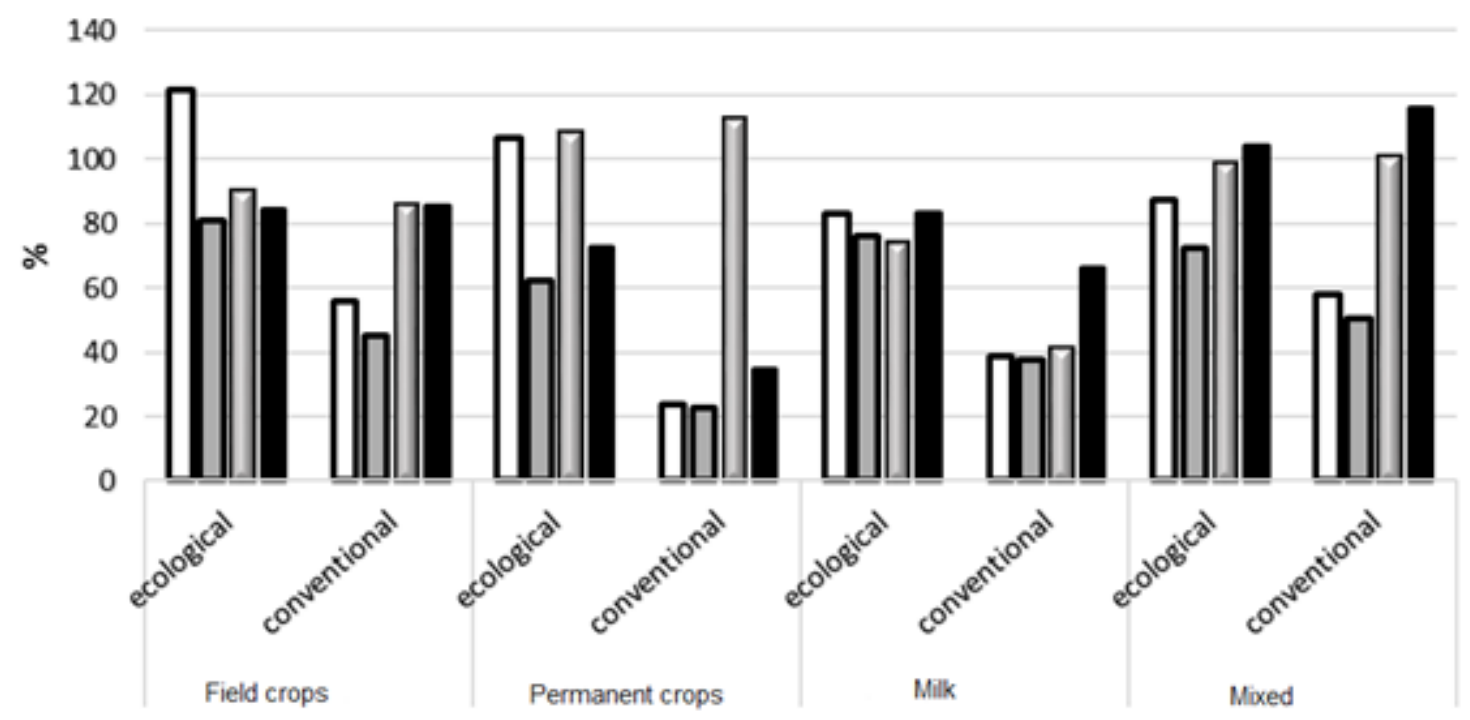

\begin{tabular}{|llll}
\hline $\mathbf{Q} 2010$ & $\mathbf{Q} 2012$ & $\mathbf{Q} 2014$ & $\mathbf{Q} 2015$
\end{tabular}

Fig. 4. Contribution of operating subsidies for ecological and conventional farms by agricultural types Source: own calculations based on: FADN, 2012a, 2012b, 2014a, 2014b, 2016a, 2016b, 2017a, $2017 \mathrm{~b}$.

It is not easy to determine whether these payments compensate the "losses" suffered by farmers with more extensive production systems. It can be done by assessing the income gap between green and conventional producers. This, nevertheless, is a far-reaching simplification for various reasons, including the fact that farms are characterized by many diverse variables (such as soil quality, productive inputs etc.). However, as indicated by Nachtman (2010), conventional production is more beneficial (in economic terms) than environmentallyfriendly production systems. A comparison of green and semi-conventional farms has led to the conclusion that financial assistance made it possible for most of the ecofriendly farms to survive (depending on the area of arable land, the share of assistance in their income ranged from $81.3 \%$ to $125.3 \%$ in 2013 ), while also representing a compensation for low soil productivity. Mixed production farms (partially green, partially conventional ${ }^{2}$ ) were more often capable of generating higher incomes, with

${ }^{2}$ The study by Nachtman (2015) examines two groups of farms: those engaged in a $100 \%$ green production system and those who carry only a part of their production operations in an a share of assistance ranging from 46 to $75 \%$ (Nachtman, 2015).

Figure 4 presents the share of assistance in agricultural incomes by farming type. The reason for using this classification is that production processes run under different farming types have a different environmental impact.

The data in Figure 4 indicates that different agricultural types of farms demonstrated considerably different shares of assistance in their agricultural incomes in subsequent years. The underlying reasons include the variable levels of income earned. Usually, green farms reported a greater share of assistance than conventional ones. However, in 2014, it was the opposite for farms with permanent crops and mixed crops; it was similar in 2015 for mixed-type farms. This may indicate an insufficient level of compensation payments for green farmers. Many researchers (including Brodova, 2008; Brodzińska, 2014; Runowski, 2012; Wrzaszcz and Zegar, 2014) emphasize that measures should be taken

environmentally friendly manner while also running conventional farming activities (mixed farms). 
to compensate for the loss of economic benefits suffered by farmers due to green production patterns. This can be justified, as pointed out by Brodova, by the fact that agriculture, apart from its basic function of food production, also has an impact on agricultural landscape and biodiversity. Since market prices of products are not always enough to cover the loss of economic benefits suffered by green farms, the society must support the manufacturers who "provide" positive externalities to perpetuate them (Brodova, 2008).

\section{CONCLUSION}

The society has become increasingly aware of negative effects of farming and the associated costs. Just like all entrepreneurs, farmers want to achieve satisfactory economic outcomes. Thus, they are willing to take advantage of available production technologies (e.g. to increase production intensity) in order to reap high benefits. If, for various reasons, a consumer decides not to pay higher prices for products that are manufactured in a way to minimize the negative externalities, it is necessary to search for other instruments that curb this adverse phenomenon, leading to the "social optimum."

The solutions applied so far (e.g. payments for agricultural practices that are favorable to the climate and the environment) cover, to a partial extent, the farming income gap. However, the incompleteness or inaccessibility of information, as well as the subjective nature of assessments of relevant processes, make it difficult to find the right solutions. It would require a detailed research at farm level, addressing the differences in production conditions which may exist between farms even tough they represent the same agricultural type; this aspect is not taken into account under the current system of farming subsidies.

\section{SOURCE OF FINANCING}

Financial resources of the Faculty of Economic Sciences, Warsaw University of Life Sciences.

\section{REFERENCES}

Baumol, W. J., Oates, W. E. (1988). The Theory of Environmental Policy. Cambridge University Press.

Begg, D., Fischer S., Dornbusch R. (1999). Mikroekonomia [Microeconomics]. Warszawa: PWE [in Polish].
Borowy, T., Kubiak, M. S. (2014). Jakość zdrowotna żywności funkcjonalnej [Health quality of functional food]. Probl. Jak., 4, 31-35 [in Polish].

Brodová, M. (2008). Quantification of non-productive functions of agricultural sector in Slovakia. Ekonomika pol'nohospodárstva, Slovak Republic.

Brodzińska, K. (2014). Rolnictwo ekologiczne - tendencje i kierunki zmian [Organic farming - trends and directions of changes]. Zesz. Nauk. SGGW Warsz. Probl. Roln. Świat., 14(XXIX), 3, 27-36.

Brodzińska, K. H. (2013). Determinanty środowiskowe i gospodarcze wdrażania programu rolnośrodowiskowego [Environmental and economic determinants of the implementation of the agri-environmental program]. Rozprawy i monografie 187. Olsztyn: Uniwersytet Warmińsko-Mazurski [in Polish].

Buks, J., Obiedzińska, A., Prandecki, K. (2016). Environmental Externalities and Food Security. J. Agribus. Rural Dev., 2(40), 257-264. DOI: 10.17306/JARD.2016.29

Cooper, T., Hart, K., Baldock D. (2009). Provision of Public Goods through Agriculture in the European Union. Report prepared for DG Agriculture and Rural Development, Contract No 30-CE-0233091/0028. London: Institute for European Environmental Policy.

Czyżewski, A., Czyżewski, B. (2013). Ziemia i jej renty w nowym paradygmacie rolnictwa [Land and its rents in the new paradigm of agriculture development]. IX Kongres Ekonomistów Polskich. Warszawa: PTE [in Polish].

FADN (2012a, 2014a, 2016a, 2017a). Wyniki standardowe 2010, 2012, 2014 i 2015 uzyskane przez ekologiczne gospodarstwa rolne uczestniczące w Polskim FADN, Część I [Standard Results of Polish FADN agricultural holdings, 2010, 2012, 2014, 2015 obtained by ecological farms, part I; Standard Results of Polish FADN agricultural holdings 2010, 2012, 2014, 2015, Warsaw] Part I [in Polish].

FADN (2012b, 2014b, 2016b, 2017b). Wyniki standardowe 2010, 2012, 2014 i 2015 uzyskane przez gospodarstwa rolne uczestniczące w Polskim FADN [Standard Results of Polish FADN agricultural holdings 2010, 2012, 2014, 2015, Warsaw].

Gołębiewska, B. (2011). Efekty zewnętrzne produkcji rolniczej i ich wpływ na dochody gospodarstw [Externalities of Agricultural Production and Their Influence on Farm Income]. Rocz. Nauk. SERiA, XII, 4 [in Polish].

Gołębiewska, B., Pajewski, T. (2016). Negatywne skutki produkcji rolniczej i możliwości ich ograniczania [The negative effects of agricultural production and the possibility of its limitation]. Rocz. Nauk. SERiA, XVIII, 3 [in Polish].

Graczyk, A. (2005). Ekologiczne koszty zewnętrzne. Identyfikacja, szacowanie, internalizacja [Ecological external 
costs. Identification, estimation, internalization]. Białystok: Wyd. Ekonomia i Środowisko [in Polish].

Grosse, T. G., Hardt Ł. (2010). Sektorowa czy zintegrowana czyli o optymalnej strategii rozwoju polskiej wsi [Sectoral or integrated, that is, the optimal strategy for the development of the Polish countryside]. Warszawa: „Pro Oeconomia" Fundacja Ewaluacji i Badań Ekonomicznych [in Polish].

Jongeneel, R., Polman, N., van der Ham, C. (2014). Costs and benefits associated with the externalities generated by Dutch agriculture. Paper to be presented at the 14th EAAE Congress in Ljubljana, s. 1-14. Retrieved June $16^{\text {th }} 2017$ from: https://ageconsearch.umn.edu/bitstream/182705/2/

Kamerschen, D. R., McKenzie, R. B., Nardinelli, C. (1991). Ekonomia [Economics]. Gdańsk: Fundacja Gospodarcza NSZZ "Solidarność" [in Polish].

Kutkowska, B. (2012). Nowe funkcje obszarów wiejskich na przykładzie terenu sudeckiego [New Functions of Rural Areas on the Example of Sudety Terrains]. Nierów. Społ. Wzrost Gospod., 29, 97-110 [in Polish].

Moffat, D. W. (1984). Economics dictionary. Second edition. New York-Amsterdam-Oxford: Elsevier.

Mroczek, J. R., Kostecka, J., Korczyńska, M. (2013). Ocena roli programu rolnośrodowiskowego w postrzeganiu przez rolników wybranych aspektów problematyki środowiskowej [The assessment of the role of agri-environmental program in the perception by farmers selected aspects of environmental issues]. Inż. Ekol., 34, 189-197 [in Polish]

Nachtman, G. (2010). Ocena dochodów gospodarstw ekologicznych na tle gospodarstw konwencjonalnych w 2008 roku w świetle danych polskiego FADN. Zagad. Doradz. Roln., 3 [in Polish].

Nachtman G. (2015). Gospodarstwa łączące ekologiczne i konwencjonalne metody produkcji na tle ekologicznych [Farms Combining Organic and Conventional Production Methods at the Background of Organic Farms]. Zagad. Ekon. Roln., 3(344), 129-147 [in Polish].

Piskuła, M. K., Strączkowski, M., Żmudzki, J., Osek, J., Niemczuk, K., Horbańczuk, J. O., Skomiał, J. (2011). Charakterystyka czynników decydujących o bezpieczeństwie konsumentów i jakości prozdrowotnej żywności
[The characteristic of consumer safety- and pro health food quality- determining factors]. Pol. J. Agron., 7, 82-91 [in Polish].

Pretty, J. N., Brett, C., Gee D., Hine, R. E., Mason, C. F., Morison J. I., Raven, H., Rayment, M. D., van der Bijl, G. (2000). An Assessment of the Total External Costs of UK Agriculture. Agric. Syst., 65(2), 113-136.

Reisch, E., Ziedes, J. (1995). Wprowadzenie do ekonomiki i organizacji gospodarstw rolnych [Einführung in die landwirtschaftliche Betriebslehre] (v. 2, iss. III). Poznań: Wyd. Akademii Rolniczej w Poznaniu [in Polish].

Runowski, H. (2012). Rolnictwo ekologiczne w Polsce - stan i perspektywa [Organic farming in Poland - state and perspective]. In: J. Zegar (Ed.), Z badań nad rolnictwem społecznie zrównoważonym. Program wieloletni 2011-2014 (p. 38-78). Warszawa: IERiGŻ-PIB [in Polish].

Sadowski, A., Czubak, W. (2010). Ocena i efekty funkcjonowania programu rolnośrodowiskowego $\mathrm{w}$ Wielkopolsce [Evaluation and effects of the agri-environmental measure in Wielkopolska Region]. Rocz. Nauk. SERiA, 12(2), 303-308 [in Polish].

Samuelson, P., Nordhaus, W. (2006). Ekonomia [Economy] (v. 1). Warszawa: Wyd. Nauk. PWN [in Polish].

Stiglitz, J. E. (2004). Ekonomia sektora publicznego [Economics of the Public Sector]. Warszawa: Wyd. Nauk. PWN [in Polish].

Wilkin, J. (Ed.). (2010). Wielofunkcyjność rolnictwa. Kierunki badań, podstawy metodologiczne i implikacje praktyczne [Multifunctional agriculture. Research trends, methodological basis and practical implications]. Warszawa: IRWiR PAN [in Polish].

Wilkin, J. (2011). Wielofunkcyjność wsi i rolnictwa, a rozwój zrównoważony [Sustainable Development and the Multifunctionality of Agriculture and Rural Areas]. Wieś Roln., 4(153), 27-39 [in Polish].

Wrzaszcz, W., Zegar, S. (2014). Gospodarstwa ekologiczne w latach 2005-2010 [Organic farms in 2005-2010]. Zagad. Ekon. Rol., 2, 39-58 [in Polish].

Zegar, J. (2012). Współczesne wyzwania rolnictwa [Contemporary agriculture challenges]. Warszawa: Wyd. Nauk. PWN [in Polish]. 